\title{
Changes in bronchial responsiveness to inhaled histamine over four years in middle aged male smokers and ex-smokers
}

\author{
T K LIM, R G TAYLOR, A WATSON, H JOYCE, N B PRIDE \\ From the Department of Medicine, Royal Postgraduate Medical School, Hammersmith Hospital, London
}

\begin{abstract}
Bronchial hyperresponsiveness to inhaled histamine in smokers is associated with an accelerated annual decline in $\mathrm{FEV}_{1}$ and low baseline $\mathrm{FEV}_{1}$ values. The evolution of bronchial hyperresponsiveness and whether it precedes or follows the accelerated decline in $\mathrm{FEV}_{1}$ and reduction in $\mathrm{FEV}_{1}$ is unknown. Measurements of the provocative concentration of inhaled histamine required to reduce $\mathrm{FEV}_{1}$ by $20 \%\left(\mathrm{PC}_{20}\right)$ were repeated after a four year interval in 27 male smokers (mean age 59 years, smoking on average 27 cigarettes a day in 1986) and 16 men who were ex-smokers in 1982 and who remained non-smokers until 1986 (mean age 53 years in 1986). These men were originally recruited to a prospective study in 1974 and had their first $\mathrm{PC}_{20}$ measurement in 1982 . $\mathrm{PC}_{20}$ was positively related to baseline $\mathrm{FEV}_{1}$ in both smokers and ex-smokers in both 1982 and 1986 ( $\mathrm{r}$ ranging from 0.56 to $0.76, p<0.01$ ). In smokers mean $F E V_{1}$ fell from $83 \%$ to $77 \%$ predicted $(p<0.001)$ and geometric mean $\mathrm{PC}_{20}$ from $7 \cdot 11$ to $3.27 \mathrm{mg} / \mathrm{ml}(\mathrm{p}<0.001)$ between 1982 and 1986. The change in $\mathrm{PC}_{20}$ in individual smokers over the four years was related to change in $\mathrm{FEV}_{1}(\mathrm{p}=0.012)$. In ex-smokers mean FEV, was $93 \%$ predicted both in 1982 and in 1986 and there was no significant difference in geometric mean $\mathrm{PC}_{20}$ between $1982(6.68 \mathrm{mg} / \mathrm{ml})$ and $1986(5.98 \mathrm{mg} / \mathrm{ml})$. Thus in smokers there was an accelerated annual decline in $\mathrm{FEV}_{1}$ and an increase in bronchial hyperresponsiveness as $F E V_{1}$ fell. The ex-smokers had comparable levels of bronchial hyperresponsiveness in 1982. Mean $P_{20}$ values were unchanged in 1986 in these men, who showed a normal age related decline in $\mathrm{FEV}_{1}$. These longitudinal results emphasise the importance of baseline airway geometry in influencing bronchial hyperresponsiveness to histamine in middle aged smokers and ex-smokers.
\end{abstract}

\section{Introduction}

Longitudinal studies have shown that only a minority of cigarette smokers develop progressive deterioration of lung function sufficient to lead to appreciable disability. ${ }^{1}$ More than 20 years ago Dutch workers proposed that susceptible smokers might be those individuals who showed non-specific bronchial hyperresponsiveness, ${ }^{2}$ and subsequent studies have shown that smokers with an accelerated decline in lung function show bronchial hyperresponsiveness to methacholine $^{3}$ and histamine. ${ }^{45}$ Although these findings are consistent with the "Dutch hypothesis," they do not distinguish between this hypothesis and

Address for correspondence: Dr N B Pride, Department of Medicine, Royal Postgraduate Medical School, London W12 0HS. (Reprints will not be available.)

Accepted 9 May 1988 the possibility that the increased responsiveness is a consequence of accelerated decline in lung function. The natural history of established bronchial hyperresponsiveness in smokers and ex-smokers is unknown. In this paper we describe changes in FEV and bronchial response to inhaled histamine between 1982 and 1986 in 27 men who continued to smoke and in 16 male ex-smokers who continued not to smoke.

\section{Methods}

SUBJECTS

The men studied were originally recruited to a prospective study of lung function in $1974^{6}$ and at that time any who gave a history of asthma were excluded. In 1982 the bronchial response to inhaled histamine was assessed for the first time. ${ }^{4}$ Of 223 men tested in 1982, 42 cigarette smokers and 23 ex-smokers had a provocative concentration of histamine that 
reduced $\mathrm{FEV}_{1}$ by $20 \%\left(\mathrm{PC}_{20}\right)$ of less than 32 $\mathrm{mg} / \mathrm{ml}$. In 1986 we restudied baseline $\mathrm{FEV}_{1}$ and bronchial response to histamine in all the available men who had had a $P_{20}$ below $32 \mathrm{mg} / \mathrm{ml}$ in 1982 and who had maintained consistent smoking habits in the interval - a total of 27 continuing cigarette smokers and 16 ex-smokers who had already stopped smoking in 1982 and had not resumed smoking in the years before our repeat study in 1986 . Of the 15 smokers studied in 1982 who were not restudied in 1986, two had died of bronchogenic carcinoma, five had stopped smoking or switched to cigars or pipes, and eight refused to be restudied. Four men who had stopped smoking in 1982 had resumed in 1986 and three exsmokers in 1982 declined to be restudied. Reported smoking habits were confirmed by several measurements of the fractional concentration of carbon monoxide in mixed expired gas and plasma cotinine concentrations. Subjects were not studied within six weeks of an upper or lower respiratory tract infection. None of the men was receiving bronchodilator treatment.

\section{MEASUREMENTS}

The men were studied between 0900 and 1200 hours, after first responding to a questionnaire regarding smoking habits and respiratory symptoms. Venous blood was drawn for measurement of total white blood cell counts, eosinophil counts, and total IgE levels. Skin reactivity to extracts from nine commonly inhaled antigens (grass pollen, cat and dog dander, mixed feathers, Alternaria sp, Cladosporium sp, Aspergillus fumigatus, house dust, and Dermatophagoides pteronyssinus) was assessed by prick tests in forearm skin. The response to the test was recorded as positive when the mean weal diameter was over $2 \mathrm{~mm}$. Technical details of these measurements have been described.?

Forced expiratory volume in one second $\left(\mathrm{FEV}_{1}\right)$ was measured in the standing position with a dry bellows spirometer, ${ }^{8}$ which was calibrated daily. The highest FEV , from three technically satisfactory forced expirations expressed at BTPS was taken as the baseline and compared with reference values. ${ }^{9}$ The $\mathrm{PC}_{20}$ histamine was then determined with the same equipment and technique as was used in the 1982 study. ${ }^{40}$ Subjects wore a noseclip and inhaled a solution of $0.9 \%$ saline followed by doubling concentrations of histamine phosphate $(0.5-32$ $\mathrm{mg} / \mathrm{ml}$ ) generated by a compressed air driven Wright nebuliser at a flow rate of $7.51 / \mathrm{min}$ through a mouthpiece during tidal breathing for two minutes. The output of the nebuliser, which was checked regularly, was $0.14 \mathrm{ml} / \mathrm{min}$. $\mathrm{FEV}_{1}$ was recorded at 60 and 90 seconds and then at two minute intervals to determine the lowest value after each inhalation. The challenge was terminated when $\mathrm{FEV}_{1}$ fell below $20 \%$ of the lowest post-saline value or the $32 \mathrm{mg} / \mathrm{mf}$ concentration of histamine was reached. The $\mathrm{PC}_{25}$ histamine was obtained by linear interpolation from के log dose-response curve.

ANALYSIS

The annual decline in height corrected $\mathrm{FEV}_{1}\left(\mathrm{ml} / \mathrm{m}^{3} / \mathrm{y} \varnothing\right.$ between the two measurements of histamine response was calculated by subtracting the highest baselinf value recorded in 1986 from the highest value in 1982 and dividing by the cube of the height in metres. Because four year estimates of change in $F E V_{1}$ have relatively low signal to noise ratio, we also calculate the annual change in $\mathrm{FEV}_{1}$ between 1974 and 1986 using the highest baseline value obtained in 1974. Alb $\mathrm{PC}_{20}$ and IgE values were logarithmically transformed before analysis, and geometric mean values were derived. Student's $t$ test was used to compare group mean values and to determine differences in pairects observations between and within groups. The change in $\mathrm{PC}_{20}\left(\triangle \mathrm{PC}_{20}\right)$ in an individual was regressed on theo change in $\mathrm{FEV}_{1}$ to obtain the relationship between trends in the two measurements over the four years: $P$ values below 0.05 were considered statisticallys significant.

\section{Results}

In 1986 the mean (SEM) reported cigarette consump 3 tion for smokers was $27(2.5)$ per day. The ex-smokers who had stopped smoking for a mean period of 11 ( $2 \Phi$. years and a minimum of 5 years, were younger and had significantly more features suggestive of atopy with larger number of positive skin test responses anç higher total serum IgE levels (table 1). Nevertheless: there was no significant correlation between $\mathbf{P C}_{20}$. values and either skin test scores or IgE levels and nQ significant difference in either $\mathrm{FEV}_{1}$ or $\mathrm{PC}_{20}$ values between men with two or more positive skin prick responses and those with less than two positivi responses. Current smokers had significantly higher. total white cell counts than ex-smokers, although thes absolute eosinophil counts were not different.

Baseline $\mathrm{FEV}_{1}$ was significantly related to $\mathrm{PC}_{20}$ i both smokers and ex-smokers in $1982(r=0.69$ and $0.67, \mathrm{p}<0.01$ for both) and in $1986(\mathrm{r}<0.56$ anष $0.76, \mathrm{p}<0.001$ ) (fig 1). Similar relationships wete found when $F E V_{1}$ was expressed as a percentage of the predicted value. Though ex-smokers had larger baseline FEV $_{1}$ values (both absolute values and $\%$ predicted) than continuing smokers in 1986, the response to histamine did not differ significantlo between smokers and ex-smokers (table 1). Indeec histamine responsiveness at a given FEV, \% predicte value appeared to be slightly greater in our ex-smokers 
Table 1 Baseline data (mean (SEM) values) for smokers and ex-smokers in 1982 and 1986

\begin{tabular}{|c|c|c|c|}
\hline & $\begin{array}{l}\text { Ex-smokers } \\
(n=16)\end{array}$ & $\begin{array}{l}\text { Smokers } \\
(n=27)\end{array}$ & $p$ \\
\hline $\begin{array}{l}\text { Measurements in } 1986 \\
\text { Age }(y) \\
\text { Height }(\mathrm{m}) \\
\text { No of positive skin responses } \\
\text { WBC }\left(\times 10^{9} / 1\right) \\
\text { Eos }\left(\times 10^{9} / 1\right)\end{array}$ & $\begin{array}{ll}53 & (2.7) \\
1.76 & (0.01) \\
1.6 & (0.4) \\
6.75 & (0.3) \\
0.25 & (0.02)\end{array}$ & $\begin{array}{ll}59 & (1.2) \\
1.73 & (0.01) \\
0.3 & (0.1) \\
8.81 & (0.5) \\
0.26 & (0.02)\end{array}$ & $\begin{array}{l}0.02 \\
0.096 \\
0.01 \\
0.002 \\
0.79\end{array}$ \\
\hline $\begin{array}{l}\operatorname{IgE}(\mathrm{U} / \mathrm{ml}) \\
\log _{10} \\
\text { geometric mean }\end{array}$ & $\begin{array}{l}2.12 \\
131.0\end{array}$ & $\begin{array}{l}1.64 \\
43.7\end{array}\left(\begin{array}{c}(0 \cdot 11) \\
\end{array}\right.$ & 0.01 \\
\hline $\begin{array}{l}\mathrm{PC}_{20}(\mathrm{mg} / \mathrm{ml}) \\
1982 \log _{10} \\
\text { geometric mean } \\
1986 \log _{10} \\
\text { geometric mean }\end{array}$ & $\begin{array}{l}0.825(0.09) \\
6.68 \\
0.777(0.12) \\
5.98\end{array}$ & $\begin{array}{l}0.852(0 \cdot 09) \\
7 \cdot 11 \\
0 \cdot 515(0 \cdot 10) \\
3 \cdot 27\end{array}$ & $\begin{array}{l}0.83 \\
0.10\end{array}$ \\
\hline $\begin{array}{l}\text { FEV }_{1}(1) \\
1982 \\
1986\end{array}$ & $\begin{array}{ll}3.27 & (0.16) \\
3.15 & (0.18)\end{array}$ & $\begin{array}{ll}2.66 & (0.11) \\
2.38 & (0.11)\end{array}$ & $\begin{array}{l}0.004 \\
0.001\end{array}$ \\
\hline $\begin{array}{l}\text { FEV }_{1}(\% \text { pred }) \\
1982 \\
1986\end{array}$ & $\begin{array}{ll}93.0 & (4.0) \\
93.0 & (4.0)\end{array}$ & $\begin{array}{l}83.0 \\
77.0\end{array}$ & $\begin{array}{l}0.057 \\
0.0056\end{array}$ \\
\hline
\end{tabular}

WBC-total white blood cell count in peripheral blood; Eos - total blood eosinophil count; IgE-total serum IgE; PC 20 -provocative concentration of histamine causing a $20 \%$ full in $\mathrm{FEV}_{1}$.

FEV $(1)$ CURRENT SMOKERS

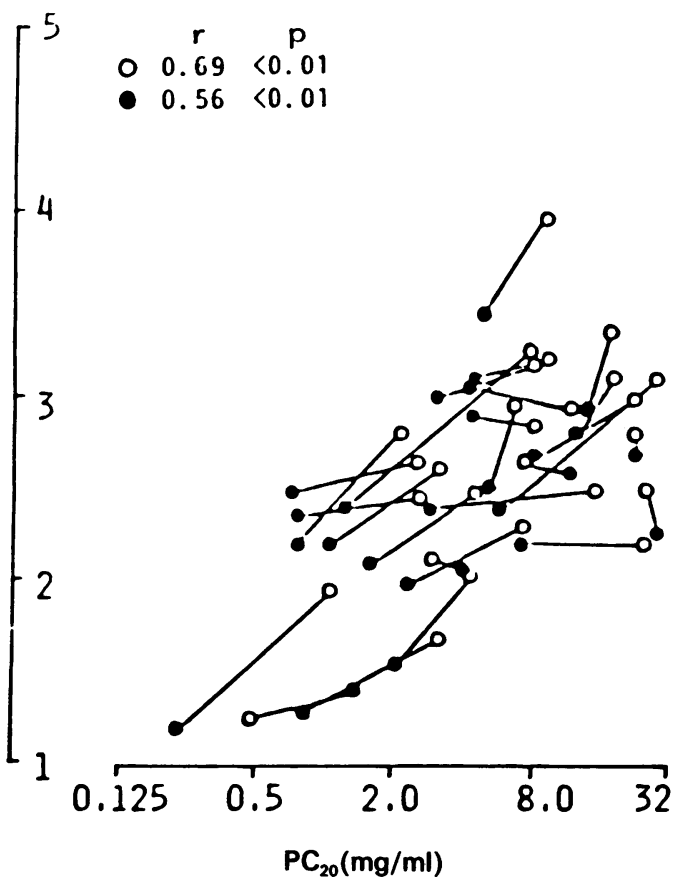

FEV,$(1)$ EX-SMOKERS

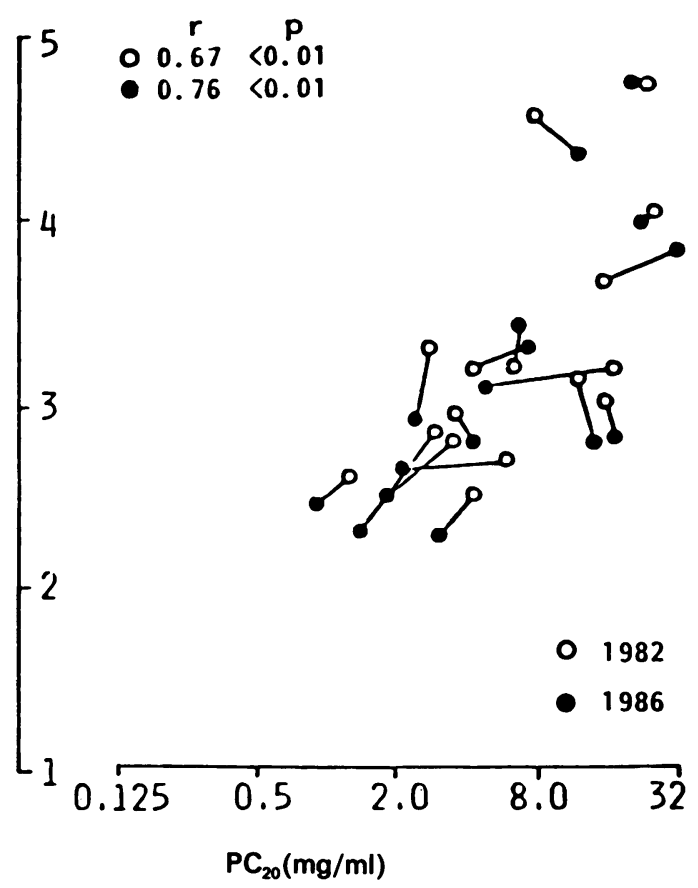

Fig 1 Relation between baseline $F E V$, and histamine responsiveness (expressed as the provocative concentration causing a $20 \%$ fall in FEV,$P C_{20}$ ) in 27 smokers (left panel) and 16 continuing ex-smokers (right panel). Measurements in 1982 (O) and $1986(\bullet)$ in each subject are joined by solid lines. Correlation coefficients $(r)$ are shown for the relation between FEV, and $P C_{21}$ in 1982 and 1986. 
Table 2 Mean (SEM) changes with time in FEV, and histamine responsiveness $\left(P C_{20}\right)$ in smokers $(S)$ and ex-smokers $(X S)^{*}$

\begin{tabular}{|c|c|c|c|}
\hline & $\begin{array}{l}\text { Ex-smokers } \\
(n=16)\end{array}$ & $\begin{array}{l}\text { Smokers } \\
(n=27)\end{array}$ & $\stackrel{p}{(X S \vee S)}$ \\
\hline \multicolumn{4}{|l|}{$1982-6$} \\
\hline $\begin{array}{l}\text { Annual } \triangle \mathrm{FEV}_{1} / \mathrm{ht}^{3}\left(\mathrm{ml} / \mathrm{m}^{3} / \mathrm{y}\right) \\
\Delta \mathrm{PC}_{20}(\mathrm{mg} / \mathrm{ml})\end{array}$ & $5 \cdot 9 \quad(2 \cdot 3)$ & $13 \cdot 9 \quad(2 \cdot 2)$ & 0.02 \\
\hline $\begin{array}{l}\Delta \log _{10} \\
\Delta \text { geometric mean } \dagger\end{array}$ & $\begin{array}{l}0.0492(0.053) \\
1 \cdot 12^{*}\end{array}$ & $\begin{array}{l}0.336(0.061) \\
2.17\end{array}$ & 0.0007 \\
\hline $\begin{array}{l}1974-6 \\
\text { Annual } \triangle \mathrm{FEV}_{1} / \mathrm{ht}^{3}\left(\mathrm{ml} / \mathrm{m}^{3} / \mathrm{y}\right)\end{array}$ & $8 \cdot 3 \quad(1 \cdot 1)$ & $13 \cdot 4 \quad(1 \cdot 1)$ & 0.03 \\
\hline
\end{tabular}

*Changes in all measurements over time were significant (paired $t$ test), $\mathrm{p}<0.001$, except change in $\mathrm{PC}_{20}$ in ex-smokers $(*, \mathrm{p}=0.37)$. † Ratio of geometric mean $\mathrm{PC}_{20} 1982$ to geometric mean $\mathrm{PC}_{20} 1986$.

than in the continuing smokers (fig 2).

There was a good correlation between values of $\mathrm{PC}_{20}$ measured in 1982 and in 1986 in individual smokers and ex-smokers (fig 1). Between 1982 and 1986 mean values of $\mathrm{FEV}_{1}$ (in litres and as \% pred) and $\mathrm{PC}_{20}$ declined significantly in smokers (mean decline 70 $\mathrm{ml} /$ year) but only absolute $\mathrm{FEV}_{1}$ declined significantly in ex-smokers (table 2) (fig 2). Indeed, FEV when $_{1}$ expressed as \% pred was identical in 1982 and 1986 in ex-smokers.

In individual smokers the change in $\mathrm{PC}_{20}$ over four years $(1982-6)$ was positively related to the decline in $\mathrm{FEV}_{1}$ (expressed as $\left.\mathrm{ml} \cdot \mathrm{m}^{-3} \cdot \mathrm{y}^{-1}\right) \quad(\mathrm{r}=0.463$, $\mathrm{p}=0.012$ ). The regression of $\triangle \log \mathrm{PC}_{20}$ on $\triangle F E V_{1}$ had a slope of 12.23 (SEM 4.55) in smokers. For ex-

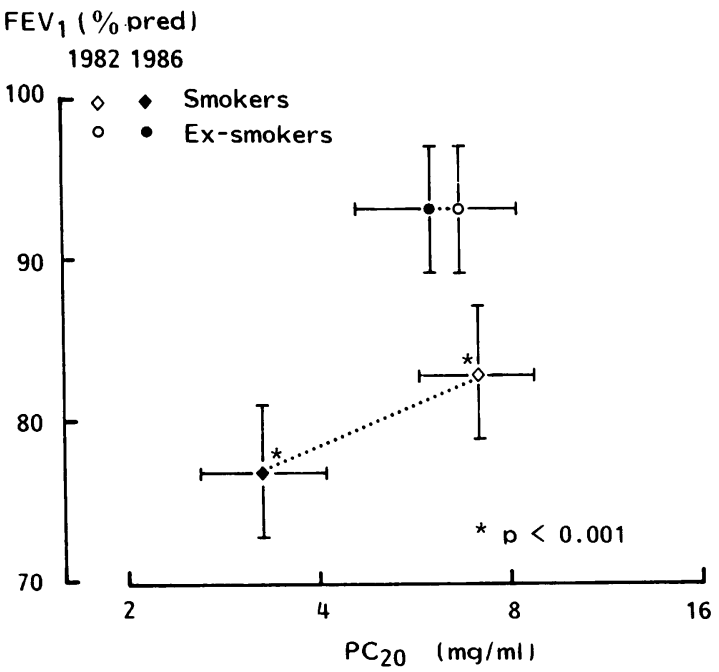

Fig 2 Comparison of geometric mean and SEM $P C_{20}$ values and baseline $F E V, \%$ pred between smokers and ex-smokers in 1982 and 1986. The open symbols represent measurements in 1982 and the closed symbols the 1986 values. The asterisks indicate a significant fall in both $F E V, \%$ pred and $P C_{20}$ in smokers over this period according to paired t tests. (Reproduced from Pride et al "by courtesy of the Bulletin Européen de Physiopathologie Respiratoire.) smokers the slope was $9 \cdot 22(5 \cdot 46)$, which did not differio significantly from zero or from the slope obtained fore smokers (difference in slopes $3.01,95 \%$ confidence interval -13.06 to 19.08 ).

The mean annual decline in $\mathrm{FEV}_{1}$ in smokers over? the 12 years 1974-86 was similar to that observed frome

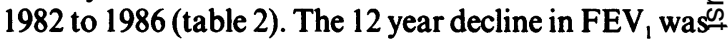
correlated negatively with 1986 values of baseline $\overrightarrow{0}$ FEV $_{1} \quad(r=-0.480, \quad p<0.02)$ and $\quad P_{2000}^{\infty}$ $(r=-0.481, p<0.02)$. In ex-smokers the annuab decline in $\mathrm{FEV}_{1}$ over 12 years was somewhat greatero than the decline during 1982-6. This was expected as in the early years of follow up some individuals weren smoking.

\section{Discussion}

Since the first descriptions in the $1960 \mathrm{~s}^{212}$ many studie have confirmed that smokers with some degree of airflow obstruction but without evidence of atopy show bronchial hyperresponsiveness to inhaled, histamine and methacholine. Moreover, smokers with bronchial hyperresponsiveness are known to have had a faster annual decline in FEV, than smokers withoug hyperresponsiveness. ${ }^{3-5} \mathrm{~A}$ reduced $\mathrm{FEV}_{1}$, however, is an important association of a low $\mathrm{PC}_{20}$ in smokers ${ }^{413-18}$ and it is also commonly associated with a preceding accelerated decline of FEV ("horseracing effect"). Because of these close interrelations between baselin $\mathrm{FEV}_{1}$, bronchial hyperresponsiveness, and rate of decline in $F E V_{1}$ it is uncertain whether hyperrespon $\tilde{O}^{-}$ siveness is important in the pathogenesis of progres sive airflow obstruction in smokers or merely consequence of its development, analogous to the development of increased vascular reactivity in hyper tension. ${ }^{17}$

In this study we have shown that smokers and ex=0 smokers who had bronchial hyperresponsiveness $i \overrightarrow{\mathbb{Q}}$ 1982 still had it in 1986. Over the four years there wa\& an association between accelerated decline in FEV $\vec{\Phi}$ and reduction in $\mathrm{PC}_{20}$ in smokers, whereas in exsmokers there was only the predicted age related decline in $\mathrm{FEV}_{1}$ and no change in mean $\mathrm{PC}_{20}$. A 
expected from our earlier analysis of the larger group that contained these men in $1982,{ }^{4}$ baseline FEV , was correlated with $\mathrm{PC}_{20}$, in both smokers and ex-smokers. Similar correlations were found in the 1986 results. These results confirm those of many other investigators who have studied patients with "chronic obstructive pulmonary disease" or middle aged smokers $^{4513-16}$; this relation is much less consistent in asthma. ${ }^{18}$

Our new finding is that as a group smokers showed a significant decline in $\mathrm{PC}_{20}$ over the four years' follow up and that in individual smokers the extent of decline in $\mathrm{PC}_{20}$ was related to the rate of annual decline in $\mathrm{FEV}_{1}$. Because we first measured bronchial responsiveness in these men when they had already smoked for many years and often had some degree of airflow obstruction, we cannot conclude that bronchial hyperresponsiveness followed rather than preceded the development of airflow obstruction in 1982, but our follow up results strongly indicate that airway geometry plays an important part in determining hyperresponsiveness. We believe that the results in ex-smokers also support this conclusion. In the ex-smokers, although on average $F E V_{\text {, in }} 1982$ was slightly below expected values, over the following four years there was only the predicted age related further decline, so that the mean FEV, value was $93 \%$ of the predicted value in both 1982 and 1986. Despite this normal rate of decline in $\mathrm{FEV}_{1}$, on average there was no attenuation of bronchial hyperresponsiveness. Because inflammatory changes, as indicated by white blood cell counts, ${ }^{7}$ cell counts from bronchoalveolar lavage fluid, ${ }^{19}$ and sputum volume, ${ }^{20}$ are usually reduced after stopping smoking, we interpret the overall lack of change in $\mathrm{PC}_{20}$ in ex-smokers as emphasising the role of geometric rather than inflammatory changes in determining $\mathrm{PC}_{20}$ in smokers. In the only other follow up studies of bronchial hyperresponsiveness in smokers we have identified, Simonsson and Rolf ${ }^{21}$ also found no attenuation of bronchoconstrictor responsiveness in two mildly responsive men in the first year after stopping smoking, while Buckzo et al ${ }^{22}$ found no change in methacholine responsiveness in 17 smokers 99 days on average after they reported stopping smoking.

When our longitudinal study started in 1974 we excluded men who gave a history of asthma or were receiving bronchodilator treatment. ${ }^{6}$ Subsequently we have analysed the significance of atopic factors (positive skin test responses to common inhalant allergens, a family history of asthma or rhinitis, raised total blood IgE and peripheral blood eosinophil counts) in the recruited $\operatorname{men}^{47}$ and found an increased prevalence of positive skin responses in ex-smokers. This, together with a higher mean value for total blood IgE, was also found in the present subgroup of exsmokers (table 1). Thus an alternative interpretation of our results in ex-smokers is that some of them had a subclinical form of asthma: in these men bronchial hyperresponsiveness might have been "endogenous," predating the onset of smoking, and stopping smoking might have been preferentially induced by symptoms related to the hyperresponsiveness. Against this alternative explanation, these men had averaged 29.7 pack years of smoking before stopping and we found no relation between $\mathrm{PC}_{20}$ and either IgE levels or skin test reactivity in the present subgroup with bronchial hyperresponsiveness, or in the larger group of exsmokers with and without bronchial hyperresponsiveness from whom these men were drawn. ${ }^{4}$

Previous studies have shown that bronchial hyperresponsiveness is associated with preceding accelerated annual decline in $\mathrm{FEV}_{1}$ in smokers; in the present study we have been able to show this prospectively, smokers showing a considerably greater rate of decline in FEV, than ex-smokers studied concurrently or than never smokers and a less selected group of smokers studied earlier in our laboratory. ${ }^{4}$ Although the follow up period of four years is relatively brief for establishing the annual rate of decline in $\mathrm{FEV}_{1}$, this is less of a problem in studying smokers with accelerated decline and similar rates were obtained when decline was calculated over a 12 year period (eight years before and four years after the first measurement of bronchial responsiveness). Further studies of the relation between $\mathrm{PC}_{20}$ in 1982 and the subsequent course of lung function are planned.

This work was supported by grants from the Medical Research Council and the Chest, Heart, and Stroke Association. T K L was the recipient of a Commonwealth medical fellowship. We are grateful to Vic Aber for statistical advice.

\section{References}

1 Fletcher CM, Peto R. The natural history of chronic airflow obstruction. Br Med J 1977; i:1645-8.

2 Van der Lende R, de Kroon JPM, van der Muelen GG, et al. Possible indicators of endogenous factors in the development of CNSLD. In: Orie NGM, van der Lende R, eds. Bronchitis III. Proceedings of the third international symposium on bronchitis, September 1969, Groningen. Assen: Royal Van Gorcum, 1970;50-72.

3 Barter CE, Campbell AH. Relationship of constitutional factors and cigarette smoking to decrease in 1-second expiratory volume. Am Rev Respir Dis 1976;113: $305-14$.

4 Taylor RG, Joyce H, Gross E, Holland F, Pride NB. Bronchial reactivity to inhaled histamine and annual rate of decline of FEV in male smokers and exsmokers. Thorax 1985;40:9-16.

5 Connellan SJ, Joyce H, Holland F, Carson R, Pride NB. 
Factors determining susceptibility to chronic airway narrowing in smokers. Thorax 1982;37:232.

6 Tattersall SF, Benson MK, Hunter D, et al. The use of tests of peripheral lung function for predicting future disability from airflow obstruction in middle-aged smokers. Am Rev Respir Dis 1978;118:1035-50.

7 Taylor RG, Gross E, Joyce H, Holland F, Pride NB. Smoking, allergy, and the differential white blood cell count. Thorax 1985;40:17-22.

8 McDermott M, McDermott TJ, Collins MM. A portable bellows spirometer and timing unit for the measurement of respiratory function. Medical and Biological Engineering 1968;6:291-3.

9 Quanjer PH, ed. Standardized lung function testing. Bull Eur Physiopathol Respir 1983;19(suppl 5):7-10.

10 Cockcroft DW, Killian DM, Mellor IJA, Hargreave FE. Bronchial reactivity to inhaled histamine: a method and clinical survey. Clin Allergy 1977;7:235-43.

11 Pride NB, Taylor RG, Lim TK, Joyce H, Watson A. Bronchial hyperreactivity as a risk factor for progressive air-flow obstruction in smokers. Bull Eur Physiopathol Respir 1987;23:369-75.

12 Klein RC, Salvaggio JE. Nonspecificity of the bronchoconstricting effect of histamine and acetylmethylcholine in patients with obstructive airway disease. J Allergy 1966;37:158-68.

13 Bahous J, Cartier A, Quimet G, Pineau L, Malo JL. Non-allergic bronchial hyperexcitability in chronic bronchitis. Am Rev Respir Dis 1984;129:216-20.

14 Mullen JBM, Wiggs BR, Wright JL, Hogg JC, Pare PD.
Nonspecific airway reactivity in cigarette smokers. Relationship to airway pathology and baseline lung function. Am Rev Respir Dis 1968;133:120-5.

15 Ramsdale EH, Morris MM, Roberts RS, Hargreave FE. Bronchial responsiveness to methacholine in chronic bronchitis: relationship to airflow obstruction and cold air responsiveness. Thorax 1984;39:912-8.

16 Ramsdell JW, Nachtwey EJ, Moser KM. Bronchial hyperreactivity in chronic obstructive bronchitis. Am Rev Respir Dis 1982;126:829-32.

17 Folkow B. Physiological aspects of primary hypertension. Physiol Rev 1982;62:347-504.

18 Yan K, Salome CM, Woolcock AJ. Prevalence and nature of bronchial hyperresponsiveness in subjects with chronic obstructive pulmonary disease. Am Rev Respir Dis 1985;132:25-9.

19 O'Neill S, Prichard JS. Elastolytic activity of alveolar macrophages in chronic bronchitis: comparison of current and former smokers. Thorax 1983;38:356-9.

20 Fletcher CM, Peto R, Tinker C, Speizer FE. The natural history of chronic bronchitis and emphysema. Oxford: Oxford University Press, 1976.

21 Simonsson BG, Rolf C. Bronchial reactivity to methacholine in ten non-obstructive heavy smokers before and up to one year after cessation of smoking. Eur J Respir Dis 1982;63:526-34.

22 Buczko GB, Day A, Vanderdoelen JL, Boucher R, Zamel N. Effects of cigarette smoking and short-term smoking cessation on airway responsiveness to inhaled methacholine. Am Rev Respir Dis 1984;129:12-4. 